\title{
REVIEW
}

\section{The use of biomarkers to assess the health of aquatic ecosystems in Brazil: a review}

\author{
Thaís Dalzochio • Gabriela Zimmermann Prado Rodrigues • Ismael Evandro Petry • \\ Günther Gehlen · Luciano Basso da Silva
}

Received: 8 April 2016/Accepted: 19 October 2016/Published online: 3 November 2016

(C) The Author(s) 2016. This article is published with open access at Springerlink.com

\begin{abstract}
Organisms in polluted environments are typically exposed to a complex mixture of chemical contaminants. The great concern about the health of aquatic ecosystems has led to the increased use of biomarkers over the past years. The aim of this work was to review the papers published from 2000 to 2015, which used biomarkers to assess the health of aquatic ecosystems in Brazil. A research resulted in 99 eligible papers. More than $80 \%$ of studies were conducted in the states of São Paulo and Rio Grande do Sul. Approximately $63 \%$ of studies used fish as bioindicator, whereas the micronucleus test and biochemical analyses were the most used biomarkers. A multibiomarker approach was used by $60.6 \%$ of studies, while $39.4 \%$ used one single biomarker. Furthermore, $68 \%$ were field studies and more than $75 \%$ of these used control animals sampled at reference sites. A relationship between the biomarker responses and pollution was reported by $87 \%$ of studies; however, $43.4 \%$ of studies analyzed only one sampling period, limiting comparisons and comprehension about possible seasonal variations. This review evidenced some weak points in studies using biomarkers in Brazil, especially related to the lack of studies in two important biomes (the Pantanal and the Amazon Rainforest) and experimental designs (small sample size, sampling in one single period, use of one single biomarker). Thus, future studies should consider mainly the use of multiple biomarkers, greater sample size, seasonal sampling and water physicochemical parameters to better diagnose the health of aquatic ecosystems.
\end{abstract}

Keywords Biomarkers · Environmental pollution · Toxicology assessment · Water quality

T. Dalzochio $(\bowtie) \cdot$ G. Z. P. Rodrigues · G. Gehlen · L. B. da Silva

Programa de Pós-Graduação em Qualidade Ambiental, Universidade Feevale, RS 239, 2755, Novo Hamburgo,

RS CEP 93352-000, Brazil

e-mail: tdalzochio@gmail.com

G. Z. P. Rodrigues

e-mail: gabizpr@gmail.com

G. Gehlen

e-mail: guntherg@feevale.br

L. B. da Silva

e-mail: lucianosilva@feevale.br

\section{E. Petry}

Laboratório de Histologia Comparada, Universidade Feevale, RS 239, 2755, Novo Hamburgo, RS CEP 93352-000, Brazil

e-mail: ismaelevandro@hotmail.com 


\section{Introduction}

Pollution of the aquatic ecosystems is considered a serious and growing problem. Increasing amount of industrial, agricultural and urban pollutants discharged into the aquatic environment have led to various deleterious effects on aquatic organisms and also on human health (McGlashan and Hughies 2001). In Brazil, surface water quality is monitored only by the means of physicochemical and microbiological (coliforms) parameters, according to limits established by the Brazilian National Environment Council (CONAMA) (Brasil 2005). The CONAMA Resolution 357/2005 provides maximum values for certain substances in surface waters, but does not provide specific information on the use of ecotoxicological tests for assessing water quality. Furthermore, physicochemical analyses provide only information about the nature of the contaminants and their concentrations in the environment, and they cannot predict bioavailability or potential effects on biota (Seriani et al. 2015). On the other hand, ecotoxicological approaches represent a useful indicator of water quality (Gonzalez et al. 1993; Araújo et al. 2014), because they reflect the real conditions of interaction by synergy and/or antagonism among the contaminants and the effects on the organisms (Azevedo et al. 2013; Fuzinatto et al. 2013).

A biomarker can be defined as a quantitative measure of changes in molecular or cellular components, processes, structures and functions related to exposure to environmental chemicals (Depledge et al. 1995; He et al. 2012; Fasulo et al. 2013). Classes of biomarkers have been proposed according to the extent that they reflect exposure to environmental stressors, or adverse health effects from contaminant exposures (WHO 1993; van der Oost et al. 2003; Viarengo et al. 2007; Hook et al. 2014). Biliary fluorescent aromatic compounds, vitellogenin, cytochrome P4501A mRNA or protein, hepatic ethoxyresorufin- $O$-deethylase (EROD) and metallothioneins (MT) are examples of biomarkers of exposure. They show an early response to contaminants and are typically specific to a particular class of contaminants (Broeg et al. 2005). Biomarkers of effect are related to measurable biochemical, physiological or other alterations within tissues or body fluids of an organism that can be recognized as associated with an established or possible health impairment or disease. Heat shock proteins (HSP70 or HSP90), markers of oxidative stress [superoxide dismutase (SOD), glutathione, catalase (CAT), lipid peroxidation (LPO)], condition indices (condition factor, hepatosomatic index, gonadal index), histopathology evaluation, DNA damage and acetylcholinesterase (AChE) (which indicates both exposure and effects) are examples of biomarkers of biological effects (Hook et al. 2014). Yet, another class of biomarkers is described as "biomarkers that integrate chemical exposure and biological effects". They include AChE and also genomic approaches (Hook 2010). In general, some biomarkers allow the specific identification of exposure to a class of xenobiotics or alterations of physiological function, but the majority of biomarker applications monitor a general response to disturbance (Trapp et al. 2014). Nevertheless, it is important to note that many non-pollution factors may interfere with biomarker responses. These "confounding" factors include the organisms' health, sex, age, nutritional status, metabolic activity, migratory behavior, reproductive and development status, and population density, as well as factors like season, ambient temperature, heterogeneity of the environmental pollution and so forth (van der Oost et al. 2003).

The use of biomarkers with the purpose of biomonitoring natural aquatic systems by the use of bioindicator species is necessary to efficiently measure the degree of exposure in aquatic organisms to chemical contaminants (Sureda et al. 2011). Biomonitoring or biological monitoring can be defined as the systematic use of biological responses to evaluate changes in the environment (Cairns and van der Schalie 1980). In this context, biomarkers are increasingly worldwide-recognized tools for the assessment of pollution impacts, and some are already incorporated in environmental monitoring programs in other countries (Viarengo et al. 2007), although their systematic and large scale application is rare (Trapp et al. 2014). In this context, considering the increased contamination of water resources and the potential risk to biodiversity conservation and human health, as well as the importance of the use of biomarkers to complement the water physicochemical analysis, this study aims to review the use of biomarkers in the assessment of aquatic ecosystems health in the last 16 years in Brazil. 


\section{Data survey}

The papers were searched using the databases Science Direct and Scientific Electronic Library Online (SCIELO). The keywords used on the search were biomarker, biomonitoring, water pollution and Brazil. The criteria for the selection of papers included original articles and short communications published between January 2000 and July 2015. Studies should be performed in field and/or laboratory (with native or commercially acquired organisms) and use at least one type of biomarker in any organism exclusively aquatic (including larvae) to assess the water quality of natural environments, such as rivers, lakes, wetlands, streams and sea in Brazil. The exclusion criteria were studies related to the assessment of water quality from environments altered by constructions of reservoirs and dams, as well as studies using semiaquatic organisms (biphasic life cycle).

A qualitative analysis was conducted considering the bioindicator organism, type of study (field, in laboratory or with caged organisms), type of biomarkers, use of control or reference site, number of sampling sites, number of collections, sample size, combination of biomarkers, physicochemical parameters analyses and the response of the bioindicator to the environmental contamination.

\section{Published studies}

Considering the criteria aforementioned, 99 papers published in national and international scientific journals were selected (Table 1).

Regarding the number of publications along the years, less than five papers were published per year from 2000 to 2005. A peak of publications was reached in 2007 (13 papers) and 6-11 papers were published per year from 2008 to 2015 (Fig. 1). These data show that scientific publication in the field of aquatic ecotoxicology is stable and without tendency of increase in Brazil.

A higher number of studies carried out in Southeastern and Southern regions were observed, corresponding to more than $80 \%$ of total studies (Table 2). Most studies were carried out in the states of São Paulo, in Southeastern region (26\%) and Rio Grande do Sul, in Southern region (21\%), probably because some of the most polluted rivers in Brazil are located in these states, such as Sinos River, Gravataí River and Caí River, in Rio Grande do Sul; and Tietê River and Paraíba do Sul River, in São Paulo (Hupffer et al. 2013). In addition, these states present well-structured universities and research centers, and also receive more funding for this type of research. It is relevant to note the lack of studies published about the Midwestern region (one single study) and Northern region (three studies) despite the existence of two important biomes of Brazil in these regions - the Pantanal and Amazon Rainforest, respectively. According to Carvalho-Neta and Abreu-Silva (2010) and Montes et al. (2010), the lack of studies using biomarkers as predictors of aquatic health in these regions, and also in the Northeast, indicates the need of biomonitoring studies that might estimate the potential effects suffered by native species.

\section{Bioindicator organisms}

Various organisms have been considered as bioindicators of environmental quality. In Brazil, 62.6\% were carried out exclusively with fish, 35.4\% used other organisms, such as bivalves, plants and gastropods, and 3\% used two types of bioindicators simultaneously (Table 3). Studies using biomarkers in larvae were not found.

Fish have been considered suitable organisms for biomonitoring studies as they are sensible to changes in the aquatic environment. Their biological responses change, even at low levels of pollution (Linde-Arias et al. 2008b; Souza et al. 2013). Fish can be found virtually everywhere in the aquatic environment and they play a major ecological role in aquatic food webs as carriers of energy from lower to higher trophic levels (van der Oost et al. 2003). Thus, genetic, biochemical, behavioral and morphological responses represent useful biomarkers in environmental biomonitoring (Pesce et al. 2008; Ballesteros et al. 2009). In addition, the high percentage of studies carried out using fish as bioindicator can also be explained by the simple fish sampling techniques. 
Table 1 Summary of studies using biomarkers to assess the health of aquatic ecosystems in Brazil, in chronological order

\begin{tabular}{|c|c|c|c|}
\hline & Study & Bioindicator & Species \\
\hline 1 & Bainy et al. (2000) & Bivalve & Perna perna \\
\hline 2 & Schulz and Martins-Junior (2001) & Fish & Astyanax fasciatus \\
\hline 3 & Torres et al. (2002) & Bivalve & Mytella guyanensis \\
\hline 4 & Ventura et al. (2002) & Fish & Orthopristis ruber \\
\hline 5 & Andrade et al. (2004) & Fish & Mugil sp. and Netuma sp. \\
\hline 6 & Geracitano et al. (2004) & Worm & Laeonereis acuta \\
\hline 7 & Parente et al. (2004) & Fish & Oreochromis niloticus \\
\hline 8 & $\begin{array}{l}\text { Ranzani-Paiva and Silva-Souza } \\
\text { (2004) }\end{array}$ & Fish & Mugil platanus \\
\hline 9 & Alberto et al. (2005) & Fish & Astyanax fasciatus \\
\hline 10 & Prá et al. (2005) & Planaria & Girardia schubarti \\
\hline 11 & Amado et al. (2006a) & Fish & Micropogonias furnieri \\
\hline 12 & Amado et al. (2006b) & Fish & Paralichthys orbignyanus \\
\hline 13 & Silva et al. (2006) & Fish & Multispecies \\
\hline 14 & Souza and Fontanetti (2006) & Fish & Oreochromis niloticus \\
\hline 15 & Tortelli et al. (2006) & Fish & Micropogonias furnieri and Cathorops spixii \\
\hline 16 & Villela et al. (2006) & Bivalve & Limnoperna fortunei \\
\hline 17 & Zanette et al. (2006) & Bivalve & Crassostrea rhizophorae \\
\hline 18 & Camargo and Martinez (2007) & Fish & Prochilodus lineatus \\
\hline 19 & Domingos et al. (2007) & Bivalve & Crassostrea rhizophorae \\
\hline 20 & Fernandez et al. (2007) & Gastropod & Stramonita haemastoma and Thais rústica \\
\hline 21 & Ferreira-Cravo et al. (2007) & Worms & Laeonereis acuta \\
\hline 22 & Francioni et al. (2007) & Bivalve & Perna perna \\
\hline 23 & Junior et al. (2007) & Plant & Allium сера \\
\hline 24 & Lemos et al. (2007) & Fish & Pimephales promelas \\
\hline 25 & Lüchmann et al. (2007) & Shrimp & Farfantepenaeus brasiliensis \\
\hline 26 & Lupi et al. (2007) & Fish & Oreochromis niloticus \\
\hline 27 & Oliveira et al. (2007) & Fish & Multispecies \\
\hline 28 & Pereira et al. (2007) & Bivalve & Perna perna \\
\hline 29 & Silva and Martinez (2007) & Fish & Astyanax altiparanae \\
\hline 30 & Villela et al. (2007) & Bivalve & Limnoperna fortunei \\
\hline 31 & David et al. (2008) & Bivalve & Mytella falcata \\
\hline 32 & Lemos et al. (2008) & Fish & Astyanax jacuhiensis \\
\hline 33 & Linde-Arias et al. (2008a) & Fish & Oreochromis niloticus \\
\hline 34 & Linde-Arias et al. (2008b) & Fish & Oreochromis niloticus \\
\hline 35 & Medeiros et al. (2008a) & Bivalve & Crassostrea gigas \\
\hline 36 & Medeiros et al. (2008b) & Bivalve & Crassostrea gigas \\
\hline 37 & Miranda et al. (2008) & Fish & Hoplias malabaricus \\
\hline 38 & Parente et al. (2008) & Fish & Oreochromis niloticus and Geophagus brasiliensis \\
\hline 39 & Ruas et al. (2008) & Fish & $\begin{array}{l}\text { Oreochromis niloticus, Tilapia rendalli and Geophagus } \\
\text { brasiliensis }\end{array}$ \\
\hline 40 & Zanette et al. (2008) & Bivalve & Crassostrea rhizophorae and Crassostrea gigas \\
\hline 41 & Barberio et al. (2009) & Plant & Allium сера \\
\hline 42 & Cardoso et al. (2009) & Fish & Trichiurus lepturus \\
\hline 43 & Galindo and Moreira (2009) & Fish & Bathygobius soporator \\
\hline 44 & Katsumiti et al. (2009) & Fish & Cathorops spixii \\
\hline 45 & Kirschbaum et al. (2009) & Fish & Centropomus parallelus \\
\hline 46 & Barbosa et al. (2010) & Fish and plant & Oreochromis niloticus and Allium cepa \\
\hline
\end{tabular}


Table 1 continued

\begin{tabular}{|c|c|c|c|}
\hline & Study & Bioindicator & Species \\
\hline 47 & $\begin{array}{l}\text { Carvalho-Neta and Abreu-Silva } \\
\text { (2010) }\end{array}$ & Fish & Sciades herzbergii \\
\hline 48 & Egito et al. (2010) & Fish & Crenicichla menezesi \\
\hline 49 & Franco et al. (2010) & Fish & Oreochromis niloticus \\
\hline 50 & Montes et al. (2010) & Fish & Brachyplatystoma rousseauxii \\
\hline 51 & Rechenmacher et al. (2010) & Rat & Wistar rats \\
\hline 52 & Rocha et al. (2010) & Fish & Brachyplatystoma rousseauxii \\
\hline 53 & Sáenz et al. (2010) & Bivalve & Perna perna \\
\hline 54 & Santos et al. (2010) & Fish & Mugil curema \\
\hline 55 & Scalon et al. (2010) & Fish & Hyphessobrycon luetkenii \\
\hline 56 & Seriani et al. (2010) & Fish & Micropogonias furnieri \\
\hline 57 & Flores-Lopes and Thomaz (2011) & Fish & Astyanax fasciatus and Cyanocharax alburnus \\
\hline 58 & Lemos et al. (2011) & Cell culture & Human linphocytes \\
\hline 59 & Nunes et al. (2011) & $\begin{array}{l}\text { Cell culture and } \\
\text { plant }\end{array}$ & Chinese hamster lung fibroblasts and Allium сера \\
\hline 60 & Pereira et al. (2011) & Bivalve & Perna perna \\
\hline 61 & Souza-Bastos and Freire (2011) & Fish & Atherinella brasiliensis \\
\hline 62 & Toste et al. (2011) & Gastropod & Stramonita haemastoma \\
\hline 63 & Anzolin et al. (2012) & Fish & Trichechus manatus \\
\hline 64 & Azevedo et al. (2012a) & Fish & Cathorops spixii \\
\hline 65 & Azevedo et al. (2012b) & Fish & Cathorops spixii \\
\hline 66 & Carvalho et al. (2012) & Fish & Oreochromis niloticus \\
\hline 67 & Hauser-Davis et al. (2012a) & Fish & Mugil Liza \\
\hline 68 & Hauser-Davis et al. (2012b) & Fish & Oreochromis niloticus, Mugil liza and Gephafus brasiliensis \\
\hline 69 & Nascimento et al. (2012) & Fish & $\begin{array}{l}\text { Oligosarcus hepsetus, Hypostomus auroguttatus and Geophagus } \\
\text { brasiliensis }\end{array}$ \\
\hline 70 & Oliveira et al. (2012) & Plant & Allium cepa and Eichhornia crassipes \\
\hline 71 & Rola et al. (2012) & Bivalve & Mytilus edulis \\
\hline 72 & Seriani et al. (2012) & Fish & Oreochromis niloticus \\
\hline 73 & Souza et al. (2012) & Bivalve & Crassostrea gigas \\
\hline 74 & Azevedo et al. (2013) & Fish & Cathorops spixii \\
\hline 75 & Bastos et al. (2013) & Fish & Mugil sp. \\
\hline 76 & Davanso et al. (2013) & Crab & Goniopsis cruentata \\
\hline 77 & Fuzinatto et al. (2013) & Fish & Oreochromis niloticus \\
\hline 78 & Melo et al. (2013) & Fish & Multispecies \\
\hline 79 & Ribeiro et al. (2013) & Fish & Atherinella brasiliensis \\
\hline 80 & Seriani et al. (2013) & Fish & Centropomus parallelus \\
\hline 81 & Sousa et al. (2013) & Fish & Sciades herzbergii and Bagre bagre \\
\hline 82 & Souza et al. (2013) & Fish & Centropomus parallelus \\
\hline 83 & Venancio et al. (2013) & Reptile & Phrynops geoffroanus \\
\hline 84 & Batista et al. (2014) & Fish & Astyanax bimaculatus \\
\hline 85 & Castro et al. (2014) & Fish & Hoplias malabaricus \\
\hline 86 & Costa et al. (2014) & Plant & Tradescantia pallida var. purpúrea \\
\hline 87 & Factori et al. (2014) & Plant & Landoltia punctata \\
\hline 88 & Osório et al. (2014) & Fish & Geophagus brasiliensis \\
\hline 89 & Pereira et al. (2014) & Bivalve & Crassostrea rhizophorae and Perna perna \\
\hline 90 & Procópio et al. (2014) & Fish & Prochilodus argenteus \\
\hline 91 & Vieira et al. (2014) & Fish & Astyanax altiparanae \\
\hline 92 & Barrilli et al. (2015) & Fish & Astyanax paranae, Phalloceros harpagos and Poecilia reticulata \\
\hline
\end{tabular}


Table 1 continued

\begin{tabular}{llll}
\hline Study & Bioindicator & Species \\
\hline 93 & Bueno-Krawczyk et al. (2015) & Fish & Astyanax bifasciatus \\
94 & Cruz et al. (2015) & Fish & Oreochromis niloticus \\
95 & Gomes et al. (2015) & Plant & Allium cepa \\
96 & Maceda et al. (2015) & Fish and plant & Astyanax altiparanae and Allim cepa \\
97 & Prado et al. (2015) & Fish & Achirus lineatus \\
98 & Seriani et al. (2015) & Fish & Oreochromis niloticus \\
99 & Zanette et al. (2015) & Barnacles & Balanus improvisus \\
\hline
\end{tabular}

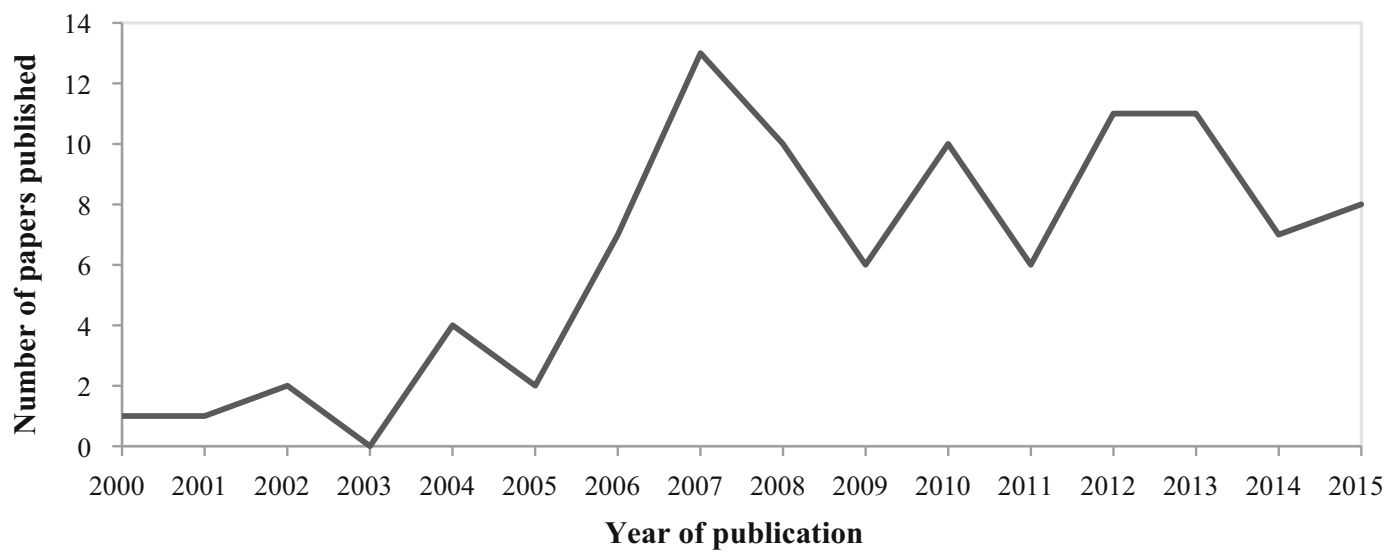

Fig. 1 Number of papers published in journals between January 2000 and July 2015 regarding the use of biomarkers to assess the water quality in Brazil

Table 2 Studies using biomarkers to assess the health of aquatic ecosystems in Brazilian regions

\begin{tabular}{lrr}
\hline Region & Number of papers & $\%$ \\
\hline Southeast & 42 & 42.4 \\
South & 42 & 42.4 \\
Northeast & 9 & 9.1 \\
North & 3 & 3.0 \\
More than one region $^{\text {a }}$ & 2 & 2.0 \\
Midwest $_{\text {Total }}$ & 1 & 1.0 \\
\hline
\end{tabular}

${ }^{a}$ Studies with sampling sites located in different Brazilian regions

Table 3 Bioindicator organisms of studies using biomarkers to assess the health of aquatic ecosystems in Brazil

\begin{tabular}{lcc}
\hline Organism & Number of studies & $\%$ \\
\hline Fish & 62 & 62.6 \\
Bivalves & 17 & 17.2 \\
Plants & 6 & 6.1 \\
Others & 11 & 11.1 \\
More than one type of bioindicator & 3 & 3.0 \\
Total & 99 & 100 \\
\hline
\end{tabular}


Bivalves were the second group most common (17.2\%). Bivalves present a wide geographic distribution, availability in different types of aquatic environments, possibility of breeding in aquacultures and are adequate for studies with caged organisms (Viarengo et al. 2007). Other bioindicator organisms, such as crabs, shrimps, worms and planarians were occasionally used. Additionally, two studies applied cell cultures of mammals' fibroblasts (V79 line) and human lymphocytes to assess water quality. Cell cultures are a useful tool in environmental evaluation, being an alternative methodology due to its easy manipulation and sensibility when exposed to physical and chemical agents; in addition, it presents good reproducibility (Rogero et al. 2003; Zegura et al. 2009). Despite the wide use in other countries (Leme and Marin-Morales 2009), the biomarkers analysis in plants to assess water quality is still unusual in Brazil since only six studies were found in the present review.

\section{Types of studies}

The studies using biomarkers for the evaluation of aquatic ecosystems can present different approaches. They can be field studies (organisms are sampled in situ), laboratory studies (water samples are collected in an area of interest and transported to the laboratory, where bioassays of exposure are conducted) and with caged organisms (animals are exposed in cages in the study area for a period of time). Considering studies carried out in Brazil, $68 \%$ were field studies, $19 \%$ were laboratory studies, $10 \%$ were with caged organisms and $3 \%$ combined laboratory and caged animals.

Complex exposure dynamics to pollutants and resulting biological responses found in the field are seldom replicated in laboratory studies (Crane et al. 2007), thus effects of pollution might be under or overestimated. Field studies comparing impacted and reference areas enable an evaluation of the health condition of organisms in their own environment, although organisms can move and potentially avoid contaminant hot spots in the field (Ward et al. 2013). In addition, it is not always possible to determine with precision the causal agent of any given alteration (Alberto et al. 2005). In this context, laboratory studies are extremely necessary to investigate the potential of an organism to be used as a bioindicator in field studies, and also enable a better understanding of chemical modes of toxicity. However, limitations of laboratory studies include the difficulty in incorporating native species into laboratory tests, problems with size and number of organisms that can be held in the laboratory and the inability of reproducing complex behaviors, such as spawning aggregation or migration (Hook et al. 2014). Moreover, less than $17 \%$ of laboratory studies were conducted with replicate. On the other hand, studies with caged organisms are more realistic than experiments conducted in laboratory in environmental assessment and present the advantage of using organisms with a known life history (Crane et al. 2007).

\section{Reference areas and laboratory controls}

Usually, tap and mineral water (for fish and bivalves assays) or distilled water (for plant assays) is used for the control group in laboratory experiments, while samplings in reference areas (areas under minor anthropogenic impact) are conducted in the field studies. However, finding clean areas can be difficult, and then, researchers choose to use controls in laboratory with animals acquired at breeding facilities and maintained in tap water, or do not use any type of control. For biomarker analysis, the use of negative control is important, although it is also possible to monitor temporal variations of a biomarker response in only one sampling site. In Brazil, taking into account only field studies and studies with caged animals, more than $75 \%$ used controls animals sampled at reference areas, whereas others used animals kept under laboratory conditions or did not use any type of control. Considering studies which reported sampling at reference sites, $27.1 \%$ found altered biomarker responses in organisms from these areas, evidencing the difficulty in finding clean areas under minor anthropic influence, and thus complicating the comparison of biomarker results. 


\section{Biomarkers used in Brazil}

Various types of biomarkers have been used to assess the effects of exposure to pollutants in water, including morphometric indexes, histopathological alterations and molecular analyses. In Brazil, the biomarkers most frequently used were the micronucleus test, the biotransformation enzyme GST, the antioxidant enzyme CAT and histopathological analyses (Table 4). Other biomarkers not listed in Table 4 include the evaluation of physiological and hematological parameters, HSP70, vitellogenin, EROD, glutathione peroxidase (GPx), hepatic CYP1A and gene expression.

The DNA damage was assessed mainly by the comet assay (or single cell gel electrophoresis) and the micronucleus test. These techniques are sensitive, rapid and extensively used as genotoxic biomarkers (Zapata et al. 2016). The micronucleus test is one of the biomarkers most widely used for in situ monitoring of genotoxic pollution (Al-Sabti and Metcalfe 1995; Bolognesi et al. 2006; Udroiu 2006). This technique is based on the quantification of whole or fragmented chromosomes that are not incorporated into the main nucleus during mitosis (Al-Sabti and Metcalfe 1995). The comet assay is also an indicator of genotoxicity and an effective biomarker for detecting DNA strand breaks, cross-links and alkali labile sites in aquatic organisms (Tice et al. 2000; Frenzilli et al. 2009).

Xenobiotic metabolism is the central detoxification process that occurs in all the organisms. Phase I enzymes are involved in the first stage of detoxification of xenobiotics compounds and implicates in enzymatic transformation of a chemically modifying lipid soluble toxin into water-soluble toxin. Most of the transformation reactions in this phase include a broad family of enzymes, cytochrome P450s (Lardone et al. 2010). Cytochrome P450s are monooxygenases responsible by a set of functions for controlling homeostasis, including the metabolism of drugs and other xenobiotics (McDonnell and Dang 2013). Phase II enzymes are involved in the second stage of the detoxification process related to enzymatic conjugation. The enzymes of this phase (as GST) modify phase I products into more water-soluble and less toxic forms (Hassan et al. 2015). Antioxidant enzymes, such as CAT and SOD, are considered biomarkers of oxidative damage. Contaminantstimulated "reactive oxygen species" (ROS) production and resulting oxidative damage may be a mechanism of toxicity in aquatic organisms exposed to a variety of pollutants (Livingstone 2001; Azevedo et al. 2013).

Histopathological analyses represent useful tools for environmental diagnosis and monitoring. This type of analysis provides a method for the detection of morphological alterations in multiple organs (Johnson et al. 1993), as gills and liver. The analysis of gills of fish and bivalves has been widely used because changes in this organ may lead to the impairment of several functions, including gas exchange, ion regulation and excretion of metabolites (Cruz et al. 2015). In addition to these characteristics, the low cost justifies the use of histopathological analyses in ecotoxicological studies.

The morphometric indexes were used in $18.2 \%$ of studies, mostly in fish species. The condition factor of the whole body (calculated using the weight and length) provides information on potential pollution impacts. Although this parameter is not very sensitive and may be affected by non-pollutant factors, such as season,

Table 4 Main biomarkers used in the assessment of health of aquatic ecosystems in Brazil

\begin{tabular}{|c|c|c|}
\hline & Number of studies & $\%$ \\
\hline Micronucleus test & 31 & 31.3 \\
\hline Glutathione-S-transferase (GST) & 28 & 28.3 \\
\hline Catalase (CAT) & 26 & 26.3 \\
\hline Histopathological analyses & 23 & 23.2 \\
\hline Comet assay & 18 & 18.2 \\
\hline Morphometric index & 18 & 18.2 \\
\hline Acetylcholinesterase/cholinesterase activity (AChE) & 16 & 16.1 \\
\hline Lipoperoxidation analysis (LPO) & 14 & 14.1 \\
\hline Metallothionein (MT) & 9 & 9.1 \\
\hline Superoxide dismutase (SOD) & 9 & 9.1 \\
\hline Others $^{\mathrm{a}}$ & 52 & 52.5 \\
\hline
\end{tabular}

${ }^{a}$ Sum of studies which used other biomarkers 
disease and nutritional level, it is used as an initial screening biomarker to indicate exposure and effects or to provide information on energy reserves (Mayer et al. 1992; Linde-Arias et al. 2008b). Its low cost, ease and rapidity makes it a valuable tool to assess preliminary effects of pollutants in fish (van der Oost et al. 2003).

The AChE enzyme occurs in cholinergic synapses and motor end plates, and is responsible for the hydrolysis of the neurotransmitter acetylcholine into choline and acetic acid. Inhibition of AChE has been associated with the mechanism of toxic action of organophosphates and carbamates insecticides (Galgani and Bocquene 1990; Payne et al. 1996; Valbonesi et al. 2003; Andreescu and Marty 2006). However, some studies assessing metal and polycyclic aromatic hydrocarbons (PAHs) exposure have also evidenced the inhibition of this enzyme (Zinkl et al. 1991; Akaishi et al. 2004; Richetti et al. 2011).

Other biomarkers analyzed include MTs and LPO. MTs are low molecular weight proteins, high cysteine content, and good heat stability that can be used as biomarkers (Langston et al. 1998). They consist of thiol groups (sulfur-hydrogen) that bind to metals, preventing oxidative stress to the organism. MT induction as a response to metal exposure is well documented in many species and is known to play a role in the detoxification to toxic metals (Amiard et al. 2006). LPO is a consequence of the decomposition of polyunsaturated fatty acid peroxides of membrane lipids, producing a complex mixture of hydroperoxides and secondary products of oxidation, as malondialdehyde (MDA) (Banerjee et al. 1999; Akhgari et al. 2003). LPO can be enhanced by exposure to xenobiotics and some trace metal in ionic form, leading to cellular damage (Viarengo et al. 1990; Montine et al. 2004; Filipak Neto et al. 2008).

Genomics is an emerging approach in biomarkers assessment. Genomics deals with the analysis of the complete genome to understand the function of single genes. On the other hand, functional genomics is based on the analysis of gene expression (transcriptomics) and comprehensive proteins/metalloproteins analysis (proteomics/metallomics) (González-Fernández et al. 2008). New approaches in functional genomics and bioinformatics can help discriminate individual chemicals, or group of chemicals among complex mixtures that may contribute to adverse biological effects (Hook et al. 2014). Furthermore, environmental metabolomics is an emerging field referred to the application of metabolomics to characterize the interactions of living organisms with their environment (García-Sevillano et al. 2015). In Brazil, these approaches are still rare since gene expression was assessed only in $3 \%$ of studies.

Multibiomarker approach (combination of two or more biomarkers) allows a better understanding of stress responses due to pollutants exposure (Domingos et al. 2007). This approach may provide results that can be complementary and help in cases when a single biomarker response is affected by non-pollutant factors. Most Brazilian studies used this approach, while 39.4\% were carried out using a single biomarker (Table 5).

In $87.8 \%$ of studies, the authors reported a relationship between the biomarker responses and pollution in the sampling areas; however, such relation is subjective in most studies given the lack of well-designed experiments or statistical support. Furthermore, the level of environmental contamination was superficially diagnosed, since $51.5 \%$ of studies reported only the analysis of physicochemical parameters that can be obtained with portable apparatus (water temperature, salinity, $\mathrm{pH}$ or dissolved oxygen). The concentrations of at least one metal were assessed in $17.2 \%$ of studies, and one single study assessed the presence of PAHs in water. Pesticides, hormones and other emergent contaminants were not assessed. Most studies provided data on the possible type of pollution (oil spills, domestic sewage discharges, agricultural runoffs and industrial effluents) only based on previous studies, and/or local observations.

Table 5 Number of biomarkers used by studies to assess the health of aquatic ecosystems in Brazil

\begin{tabular}{llr}
\hline Number of biomarkers & Number of studies & $\%$ \\
\hline One & 39 & 39.4 \\
Two & 21 & 21.2 \\
Three & 11 & 11.1 \\
Four or more & 15 & 27.8 \\
Total & 99 & 100 \\
\hline
\end{tabular}




\section{Experimental designs}

In addition to the use of a multibiomarker approach, the assessment of more than one sampling site in different sampling periods (seasonal variation) may help in the interpretation of biomarker responses. The number of sampling sites that were assessed in Brazil is shown in Table 6. Most studies were carried out in two or three sampling sites; however, $9.1 \%$ of studies analyzed one single sampling site. This is problematic because it precludes comparisons of the biomarker responses between organisms from different areas and does not provide significant information on the impacted area. Moreover, $\sim 43 \%$ of studies were carried out in one single sampling period. Therefore, comparisons between periods were not performed, and consequently, these studies do not provide data on possible seasonal variations in biomarker responses and the real contamination scenario.

An important aspect in studies related to biomarker responses is the sample size-number of individuals analyzed per site in each sampling period or exposure experiment. Small sample size may lead to inconclusive results. As sample sizes increase, their variability tends to decrease, leading to a better hypothesis testing, a higher statistical power and smaller confidence intervals (Cochran 1977). However, sometimes it is not possible to maintain a certain sample size along the experimental design, especially in field studies. Table 7 shows the sample sizes in studies with biomarkers in the assessment of aquatic ecosystems in Brazil. Studies regarding biomarker responses with less than five organisms in at least one site or sampling period corresponded to $19.1 \%$. Information on sample size was not provided or was not clear in $7.1 \%$ of studies, since only the total sample size (sum of organisms from all sampling sites studied and/or sampling periods) was reported.

\section{Conclusions}

In this review, we provide information on the use of biomarkers to assess the health of aquatic ecosystems in Brazil, in the last 16 years. In general, the approaches used in Brazilian studies did not differ from other countries. However, some shortcomings were observed. The data analyses points towards a limited use of this approach in the country (basically restricted to two regions), a great variety of organisms used as bioindicators (regional biodiversity) and different sampling patterns. A great number of studies were conducted using fish as bioindicator organisms, therefore, the analysis of others organisms should be stimulated. Furthermore, most studies used biomarkers which are easy, fast and cheap to assess, whereas biomarkers which require more funding and/or more sophisticated equipments were rare. Differently from other countries, water physicochemical analyses are still poor and fail in providing information to establish relations between biomarker responses and contaminants. In general, a good relationship between biomarker responses and environmental pollution has been observed by the authors. However, experimental designs with multiple biomarkers, greater sample size, long-term biomonitoring and knowledge about organisms' ecological aspects may enable a better data interpretation on the environmental quality, as well as the interference of non-polluting factors in the biomarker responses. Additionally, new approaches in the genomics field may be a promising tool to better understand the impacts of sublethal concentrations of pollutants on living organisms, as well as to provide information on pollution-induced genetic changes in organisms' tolerance.

Table 6 Number of sampling sites of studies using biomarkers to assess the health of aquatic ecosystems in Brazil

\begin{tabular}{lcc}
\hline Number of sampling sites & Number of studies & $\%$ \\
\hline One & 9 & 9.1 \\
Two & 31 & 31.3 \\
Three & 21 & 21.2 \\
Four & 18 & 18.2 \\
Five & 9 & 9.1 \\
Six or more & 11 & 11.1 \\
Total & 99 & 100 \\
\hline
\end{tabular}


Table 7 Sample size (number of organisms analyzed per sampling site or exposure experiment) of studies using biomarkers to assess the health of aquatic ecosystems in Brazil

\begin{tabular}{lcc}
\hline Sample size & Number of studies & $\%$ \\
\hline Less than 5 & 19 & 19.1 \\
$6-10$ & 41 & 41.4 \\
$11-20$ & 16 & 16.2 \\
$21-49$ & 9 & 9.1 \\
50 or more & 6 & 6.1 \\
Not applied & 1 & 1.0 \\
Not informed/not clear & 7 & 7.1 \\
Total & 99 & 100 \\
\hline
\end{tabular}

Acknowledgements This work was supported by Fundação de Amparo à Pesquisa do Estado do Rio Grande do Sul (FAPERGS), Conselho Nacional de Desenvolvimento Científico e Tecnológico (CNPq) and Universidade Feevale.

\section{Compliance with ethical standards}

Conflict of interest The authors declare that they have no conflict of interest in the publication.

Open Access This article is distributed under the terms of the Creative Commons Attribution 4.0 International License (http:// creativecommons.org/licenses/by/4.0/), which permits unrestricted use, distribution, and reproduction in any medium, provided you give appropriate credit to the original author(s) and the source, provide a link to the Creative Commons license, and indicate if changes were made.

\section{References}

Akaishi FM, Silva De Assis HC, Jakobi SCG, Stjean S, Couternay SC, Lima E, Wagner ALR, Scofield A, Oliveira Ribeiro CA (2004) Morphological and neurotoxicological findings in tropical freshwater fish (Astyanax sp.) after waterborne and acute exposure to water soluble fraction (WSF) of crude oil. Arch Environ Contam Toxicol 46:244-253

Akhgari M, Abdollahi M, Kebryaeezadeh A, Hosseini R, Sabzevari O (2003) Biochemical evidence for free radical-induced lipid peroxidation as a mechanism for subchronic toxicity of malathion in blood and liver of rats. Human Exp Toxicol 22:205-211

Alberto A, Camargo AFM, Verani JR, Costa OFT, Fernandes MN (2005) Health variables and gill morphology in the tropical fish Astyanax fasciatus from a sewage-contaminated river. Ecotoxicol Environ Safe 61:247-255

Al-Sabti K, Metcalfe CD (1995) Fish micronuclei for assessing genotoxicity in water. Mutat Res 343(2-3):121-135

Amado LL, Rosa CE, Leite AM, Moraes L, Pires WV, Pinho GLL, Martins CMG, Robaldo RB, Nery LEM, Monserrat JM, Bianchini A, Martinez PE, Geracitano LA (2006a) Biomarkers in croakers Micropogonias furnieri (Teleostei: Sciaenidae) from polluted and non-polluted areas from the Patos Lagoon estuary (Southern Brazil): evidences of genotoxic and immunological effects. Mar Pollut Bull 52:199-206

Amado LL, Robaldo RB, Geracitano L, Monserrat JM, Bianchini A (2006b) Biomarkers of exposure and effect in the Brazilian flounder Paralichthys orbignyanus (Teleostei: Paralichthyidae) from the Patos Lagoon estuary (Southern Brazil). Mar Pollut Bull 52:207-213

Amiard JC, Amiard-Triquet C, Barka S, Pellerin J, Rainbow PS (2006) Metallothioneins in aquatic invertebrates: their role in metal detoxification and their use as biomarkers. Aquat Toxicol 76:160-202

Andrade VM, Freitas TRO, Silva J (2004) Comet assay using mullet (Mugil sp.) and sea catfish (Netuma sp.) erythrocytes for the detection of genotoxic pollutants in aquatic environment. Mutat Res Gen Toxicol Environ Muyagen 560(1):57-67

Andreescu S, Marty JL (2006) Twenty years research in cholinesterase biosensors: from basic research to practical applications. Biomol Eng 23:1-15

Anzolin DG, Sarkis JES, Diaz E, Soares DG, Serrano IL, Borges JCG, Souto AS, Taniguchi S, Montone RC, Bainy ACD, Carvalho PSM (2012) Contaminant concentrations, biochemical and hematological biomarkers in blood of West Indian manatees Trichechus manatus from Brazil. Mar Pollut Bull 64:1402-1408

Araújo ALS, Guimarães ET, Seriani R (2014) Mutagenesis in Tradescantia pallida as a biomarker of the effects of water polluted with urban effluent. Holos Environ 14(1):97-102

Azevedo SA, Lopes B, Katsumiti A, Braga ES, Roche H, Ribeiro CAO, Bebianno MJ (2012a) Evidence of contamination by oil and oil products in the Santos-São Vicente Estuary, São Paulo, Brazil. Braz J Oceanogr 60(2):117-126

Azevedo SA, Souza J, Braga ES, Ribeiro C, Oliveira A (2012b) Nuclear abnormalities and morphometric indexes in the catfish Cathorops spixii (Ariidae) from different sites on the Southeastern Brazilian coast. Braz J Oceanogr 60(3):323-330

Azevedo JS, Braga ES, Assis HCE, Ribeiro CAO (2013) Biochemical changes in the liver and gill of Cathorops spixii collected seasonally in two Brazilian estuaries under varying influences of anthropogenic activities. Ecotoxicol Environ Safe 96:220-230 
Bainy ACD, Almeida EA, Müller IC, Ventura EC, Medeiros ID (2000) Biochemical responses in farmed mussel Perna perna transplanted to contaminated sites on Santa Catarina Island, SC, Brazil. Mar Environ Res 50:411-416

Ballesteros ML, Durando PE, Nores ML, Díaz MP, Bistoni MA, Wunderlin DA (2009) Endosulfan induces changes in swimming motility and Acetylcholinesterase activities of Jenynsia multidentata (Anablepidae, Cyprinodontiformes). Environ Pollut 157:1573-1580

Banerjee BD, Seth V, Bhattacharya A, Pasha ST, Chakraborty AK (1999) Biochemical effects of some pesticides on lipid peroxidation and free-radical scavengers. Toxicol Lett 107:33-47

Barberio A, Barros L, Voltolini JC, Mello MLS (2009) Evaluation of the cytotoxic and genotoxic potential of water from the River Paraíba do Sul, in Brazil, with the Allium cepa L. test. Braz. J Biol 69(3):837-842

Barbosa JS, Cabral TM, Ferreira DN, Agnez-Lima LF, Medeiros SR (2010) Genotoxicity assessment in aquatic environment impacted by the presence of heavy metals. Ecotoxicol Environ Safe 73(3):320-325

Barrilli GHC, Rocha O, Negreiros NF, Verani JR (2015) Influence of environmental quality of tributaries of the Monjolinho River on the relative condition factor $(\mathrm{Kn})$ of the local ichthyofauna. Biota Neotrop 15(1):1-9

Bastos FF, Hauser-Davis RA, Tobar SAL, Campos RC, Ziolli RL, Cunha Bastos VLF, Cunha Bastos J (2013) Enzymatic GST levels and overall health of mullets from contaminated Brazilian Lagoons. Aquat Toxicol 126:414-423

Batista MTO, Junior ER, Feijó-Oliveira M, Ribeiro AC, Rodrigues E, Suda CNK, Vani GS (2014) Tissue levels of the antioxidant enzymes superoxide dismutase and catalase in fish Astyanax bimaculatus from the Una River Basin. Rev Ambient Água 9(4):621-631

Bolognesi C, Perrone E, Roggieri P, Pampanin DM, Sciutto A (2006) Assessment of micronuclei induction in peripheral erythrocytes of fish exposed to xenobiotics under controlled conditions. Aquat Toxicol 78(Supp 1):S93-S98

Brasil (2005) National Environment Council—CONAMA Resolução CONAMA 357, de 2005. http://www.mma.gov.br/port/ conama/res/res05/res35705.pdf. Accessed 14 July 2016

Broeg K, Westernhagen HV, Zander S, Korting W, Koehler A (2005) The "bioeffect assessment index" (BAI): a concept for the quantification of effects of marine pollution by an integrated biomarker approach. Mar Pollut Bull 50:495-503

Bueno-Krawczyk AC, Guiloski IC, Piancini LD, Azevedo JC, Ramsdorf WA, Ide AH, Guimarães AT, Cestari MM, Silva De Assis HC (2015) Multibiomarker in fish to evaluate a river used to water public supply. Chemosphere 135:257-264

Cairns J Jr, van der Schalie WH (1980) Biological monitoring, Part I-Early warning systems. Water Res 14:1179-1196

Camargo MMP, Martinez CBR (2007) Histopathology of gills, kidney and liver of a Neotropical fish caged in an urban stream. Neotrop Ichthyol 5(3):327-336

Cardoso TP, Mársico ET, Medeiros RJ, Tortelly R, Sobreiro LG (2009) Concentração de mercúrio e análise histopatológica em músculo, rim e cérebro de peixe-espada (Trichiurus lepturus) coletados na praia de Itaipu, Niterói, Rio de Janeiro, Brasil. Ciência Rural 39(2):540-546

Carvalho CS, Bernusso V, Araújo HSS, Espíndola ELG, Fernandes MN (2012) Biomarker responses as indication of contaminant effects in Oreochromis niloticus. Chemosphere 89:60-99

Carvalho-Neta RNF, Abreu-Silva AL (2010) Sciades herzbergii oxidative stress biomarkers: an in situ study of estuarine ecosystem (São Marcos's Bay, Maranhão, Brazil). Braz J Oceanogr 58:11-17

Castro JS, Silva JS, Freitas LC, Carvalho-Neta RNF (2014) Biomarcadores histopatológicos na espécie Hoplias malabaricus (Pisces, Osteichthyes, Erythrinidae) em uma Unidade de Conservação de São Luís (MA). Arq Bras Med Vet Zootec 66(6):1687-1694

Cochran WG (1977) Sampling techniques, 3rd edn. Wiley, New York

Costa GM, Cassanego MBB, Petry CT, Benvenuti T, Rubio MAK, Rodrigues MAS, Droste A (2014) Monitoramento químico e do potencial genotóxico para o diagnóstico da qualidade de corpos hídricos. Rev Bras Ciênc Amb 32:65-74

Crane M, Burton GA, Culp JM, Greenberg MS, Munkittrick KR, Ribeiro R, Salazar MH, St-Jean SD (2007) Review of aquatic in situ approaches for stressor and effect diagnosis. Integr Environ Assess Manag 3(2):234-245

Cruz AL, Prado TM, Maciel LAS, Couto RD (2015) Environmental effects on the gills and blood of Oreochromis niloticus exposed to rivers of Bahia, Brazil. Ecotoxicol Environ Safe 111:23-31

Davanso MB, Moreira LB, Pimentel MF, Costa-Lotufo LV, Moledo DSA (2013) Biomarkers in mangrove root crab Goniopsis cruentata for evaluating quality of tropical estuaries. Mar Environ Res 91:80-88

David JAO, Salaroli RB, Fontanetti CS (2008) The significance of changes in Mytella falcata (Orbigny, 1842) gill filaments chronically exposed to polluted environments. Micron 39:1293-1299

Depledge MH, Aagaard A, Gyorkost P (1995) Assessment of trace metal toxicity using molecular, physiological and behavioral biomarkers. Mar Pollut Bull 31:19-27

Domingos FXV, Azevedo M, Silva MD, Randi MAF, Freire CA, Silva De Assis HC, Oliveira Ribeiro CA (2007) Multibiomarker assessment of three Brazilian estuaries using oysters as bioindicators. Environ Res 105:350-363

Egito LCM, Santos PE, Amaral VS, Medeiros SRB, Agnez-Lima LF (2010) Use of native species Crenicichla menezesi (Ariidae) as a model for in situ evaluation of genotoxicity in surface water. Sci Total Environ 408:6042-6046

Factori R, Leles SM, Novakowski GC, Rocha CLSC, Thomaz SM (2014) Toxicity and genotoxicity of water and sediment from streams on dotted duckweed (Landoltia punctata). Braz J Biol 74(4):769-778

Fasulo S, Mauceri A, Maisano M, Giannetto A, Parrino V, Gennuso F, D'Agata A (2013) Immunohistochemical and molecular biomarkers in Coris julis exposed to environmental pollutants. Ecotoxicol Environ Safe 73(5):873-882

Fernandez MA, Pinheiro FM, Quadros JP, Camillo E Jr (2007) An easy, non-destructive, probabilistic method to evaluate the imposex response of gastropod populations. Mar Environ Res 63:41-54

Ferreira-Cravo M, Piedras FR, Moraes TB, Ferreira JL, Freitas DP, Machado MD, Geracitano LA, Monserrat JM (2007) Antioxidant responses and reactive oxygen species generation in different body regions of the estuarine polychaeta Laeonereis acuta (Nereididae). Chemosphere 66(7):1367-1374 
Filipak Neto F, Zanata SM, Silva de Assis HC, Nakao LS, Randi MAF, Ribeiro CAO (2008) Toxic effects of DDT and methyl mercury on the hepatocytes from Hoplias malabaricus. Toxicol Vitro 22:1705-1713

Flores-Lopes F, Thomaz AT (2011) Alterações histopatológicas observadas nas brânquias de peixes como instrumento no monitoramento ambiental. Braz J Biol 71(1):179-188

Francioni E, Wagener ALR, Scofield AL, Depledge MH, Cavalier B (2007) Evaluation of the mussel Perna perna as a biomonitor of polycyclic aromatic hydrocarbon (PAH) exposure and effects. Mar Pollut Bull 54:329-338

Franco JL, Trevisan R, Posser T, Trivella DB, Hoppe R, Martins-Rosa J, Fernandes-Dinslaken D, Decker H, Inês-Tasca C, BainyLeal R, Freire-Marques MR, Dias-Bainy AC, Luiz-Dafre A (2010) Biochemical alterations in caged Nile tilapia Oreochromis niloticus. Ecotoxicol Environ Safe 73(5):864-872

Frenzilli G, Nigro M, Lyons BP (2009) The Comet assay for the evaluation of genotoxic impact in aquatic environments. Mutat Res 681(1):80-92

Fuzinatto CF, Flohr L, Melegari SP, Matias WG (2013) Induction of micronucleus of Oreochromis niloticus exposed to waters from the Cubatão do Sul River, southern Brazil. Ecotoxicol Environ Safe 98:103-109

Galgani F, Bocquene G (1990) In vitro inhibition of acetylcholinesterase from four marine species by organophosphates and carbamates. Bull Environ Contam Toxicol 45:243-249

Galindo TP, Moreira LM (2009) Evaluation of genotoxicity using the micronucleus assay and nuclear abnormalities in the tropical sea fish Bathygobius soporator (Valenciennes, 1837) (Teleostei, Gobiidae). Genet Mol Biol 32(2):394-398

García-Sevillano MA, García-Barrera T, Gómez-Ariza JL (2015) Environmental metabolomics: biological markers for metal toxicity. Electrophoresis 36:2348-2365

Geracitano LA, Monserrat JM, Bianchini A (2004) Oxidative stress in Laeonereis acuta (Polychaeta, Nereididae): environmental and seasonal effects. Mar Environ Res 58:625-630

Gomes JV, Teixeira JTS, Lima VM, Borba HR (2015) Induction of cytotoxic and genotoxic effects of Gandu River waters in the Allium cepa system. Rev Ambient Água 10(1):48-58

Gonzalez G, Crespo S, Brusle J (1993) Histo-cytological study of the liver of the cabrilla sea bass, Serranus cabrilla (Teleostei, Serranidae), an available model for marine fish experimental studies. J Fish Biol 43(3):363-373

González-Fernández M, García-Barrera T, Jurado J, Prieto-Álamo MJ, Pueyo C, López-Barea J, Gómez-Ariza JL (2008) Integrated application of transcriptomics, proteomics, and metallomics in environmental studies. Pure Appl Chem 80(2):2609-2626

Hassan I, Jabir NR, Ahmad S, Shah A, Tabrez S (2015) Certain phase I and II enzymes as toxicity biomarker: an overview. Water Air Soil Pollut 226:153

Hauser-Davis RA, Bastos FF, Oliveira TF, Ziolli RL, Campos RC (2012a) Fish bile as a biomarker for metal exposure. Mar Pollut Bull 64:1589-1595

Hauser-Davis RA, Gonçalves RA, Ziolli RL, Campos RC (2012b) A novel report of metalothioneins in fish-bile: SDS-PAGE analysis, spectrophotometry quantification and metal speciation characterization by liquid chromatography coupled to ICPMS. Aquat Toxicol 116-117:54-60

He X, Nie X, Yang Y, Liu X, Pan D, Cheng Z, Liang X (2012) Multi-biomarker responses in fishes from two tropical marine aquaculture regions of South China. Mar Pollut Bull 64:2317-2324

Hook SE (2010) Promise and progress in environmental genomics: a status report on the applications of microarray studies in ecologically relevant fish species. J Fish Biol 77:1999-2022

Hook SE, Gallagher EP, Batley GE (2014) The role of biomarkers in the assessment of aquatic ecosystem health. Integr Environ Assess Manag 10(3):327-341

Hupffer H, Figueiredo JAS, Tundisi JG (2013) Pagamento por serviços ambientais: incentivos para a proteção dos recursos hídricos e restauração da mata ciliar. Entremeios, Porto Alegre

Johnson LL, Stehr CM, Olson OP, Myers MS, Wigren CA, McCain BB, Varnasi U (1993) Chemical contaminants and hepatic lesions in winter flounder (Pleuronectes americanus) from the Northeast coast of the United States. Environ Sci Technol 27:2759-2777

Junior HM, Silva J, Arenzon A, Portela CS, Ferreira IC, Henriques JA (2007) Evaluation of genotoxicity and toxicity of water and sediment samples from a Brazilian stream influenced by tannery industries. Chemosphere 67(6):1211-1217

Katsumiti A, Domingos FXV, Azevedo M, Silva MD, Damian RC, Almeida MIM, Silva De Assis HC, Cestari MM, Rando MAF, Oliveira Ribeiro CA, Freire CA (2009) An assessment of acute biomarker responses in the demersal catfish Cathorops spixii after the Vicuña Oil Spill in a harbour estuarine area in Southern Brazil. Environ Monit Assess 152:209-222

Kirschbaum AA, Seriani R, Pereira CDS, Assunção A, Abessa DMS, Rotundo MM, Ranzani-Paiva MJT (2009) Cytogenotoxicity biomarkers in fat snook Centropomus parallelus from Cananéia and São Vicente estuaries, SP, Brazil. Genet Mol Biol 32(1):151-154

Langston WJ, Bebianno MJ, Burt GR (1998) Metal handling strategies in mollusks. In: Langston WJ, Bebianno MJ (eds) Metal metabolism in aquatic environments. Kluwer Academic Publishers, London, pp 219-283

Lardone MC, Castillo P, Valdevenito R, Ebensperger M, Ronco AM, Pommer R, Piottante A, Castro A (2010) P450-aromatase activity and expression in human testicular tissues with severe spermatogenic failure. Int J Androl 33(4):650-660

Leme DM, Marin-Morales MA (2009) Allium cepa test in environmental monitoring: a review on its application. Mutat Res 682:71-81

Lemos CT, Rödel PM, Terra NR, Oliveira NCD, Erdtmann B (2007) River water genotoxicity evaluation using micronucleus assay in fish erythrocytes. Ecotoxicol Environ Safe 66:391-401

Lemos CT, Iranço FA, Oliveira NCD, Souza GD, Fachel JMG (2008) Biomonitoring of genotoxicity using micronuclei assay in native population of Astyanax jacuhiensis (Characiformes: Characidae) at sites under petrochemical influence. Sci Total Environ 406:337-343 
Lemos AO, Oliveira NCD, Lemos CT (2011) In vitro micronuclei tests to evaluate the genotoxicity of surface water under the influence of tanneries. Toxicol In Vitro 25:761-766

Linde-Arias AR, Inácio AF, Alburquerque C, Freire MM, Moreira JC (2008a) Biomarkers in an invasive fish species, Oreochromis niloticus, to assess the effects of pollution in a highly degraded Brazilian River. Sci Total Environ 399:186-192

Linde-Arias AR, Inácio AF, Novo LA, Alburquerque C, Moreira JC (2008b) Multibiomarker approach in fish to assess the impact of pollution in a large Brazilian river, Paraíba do Sul. Environ Pollut 156:974-979

Livingstone DR (2001) Contaminant-stimulated reactive oxygen species production and oxidative damage in aquatic organisms. Mar Pollut Bull 42:656-666

Lüchmann KH, Toledo-Silva G, Bainy ACD, Marques MRF (2007) Glutathione S-transferase cytosolic isoform in the pinkshrimp, Farfantepenaeus brasiliensis, from Conceição Lagoon, Santa Catarina Island, SC, Brazil. Environ Int 33:546-549

Lupi C, Nhacarini NI, Mazon AF, Sá OR (2007) Avaliação da poluição ambiental através das alterações morfológicas nas brânquias de Oreochromis niloticus (tilapia) nos córregos Retiro, Consulta e Bebedouro, município de Bebedouro-SP. Rev Fafibe On Line 3:1-6

Maceda EB, Grisolia AB, Vaini JO, Candido LS (2015) Uso de biomarcadores para monitoramento das águas do Córrego Arara no município de Rio Brilhante, MS, Brasil. Rev Ambient Água 10(1):117-129

Mayer FL, Versteeg DJ, Mckee MJ, Folmar LC, Graney RL, McCume DC, Rattner BA (1992) Metabolic products as biomarkers, 1992. In: Huggett RJ, Kimerly RA, Mehrle PM Jr, Bergman HL (eds) Biomarkers: biochemical, physiological and histological markers of anthropogenic stress. Lewis Publishers, Chelsea, pp 5-86

McDonnell AM, Dang CH (2013) Basic review of the cytochrome p450 system. J Adv Pract Oncol 4(4):263-268

McGlashan DJ, Hughies JM (2001) Genetic evidence for historical continuity between populations of the Australian freshwater fish Craterocephalus stercusmuscarum (Atherinidae) east and west of the Great Diving Range. J Fish Biol 59:55-67

Medeiros ID, Siebert MN, Toledo-Silva G, Moraes MO, Marques MRF, Bainy ACD (2008a) Differential gene expression in oyster exposed to sewage. Mar Environ Res 66:156-157

Medeiros ID, Siebert MN, Toledo-Silva G, Rodrigues TB, Marques MRF, Bainy ACD (2008b) Induced gene expression in oyster Crassostrea gigas exposed to sewage. Environ Toxicol Pharmacol 26(3):362-365

Melo KM, Alves IR, Pieczarka JC, David JAO, Nagamachi CY, Grisolia CK (2013) Profile of micronucleus frequencies and nuclear abnormalities in different species of electric fishes (Gymnotiformes) from the Eastern Amazon. Genet Mol Biol 36(3):425-429

Miranda AL, Roche H, Randi MAF, Menezes ML, Oliveira-Ribeiro CA (2008) Bioaccumulation of chlorinated pesticides and PCBs in the tropical freshwater fish Hoplias malabaricus: histopathological, physiological, and immunological findings. Environ Int 34:939-949

Montes CS, Ferreira MAP, Santos SSD, Von Ledebur EICF, Rocha RM (2010) Branchial histopathology study of Brachyplatystoma rousseauxii (Castelnau, 1855) in the Guajará bay, Belém, Pará State, Brazil. Acta Sci Biol Sci 32:93-99

Montine KS, Quinn JF, Zhang J, Fessel JP, Roberts LJ, Morrow JD (2004) Isoprostanes and relates products of lipid peroxidation in neurodegenerative diseases. Chem Phys Lipids 128:117-124

Nascimento AA, Araújo FG, Gomes ID, Mendes RM, Sales A (2012) Fish gills alterations as potential biomarkers of environmental quality in a eutrophized tropical river in south-eastern Bazil. Anat Histol Embryol 41(3):209-216

Nunes EA, Lemos CT, Gavronski L, Moreira TN, Oliveira NCD, Silva J (2011) Genotoxic assessment on river water using different biological systems. Chemosphere 84:47-53

Oliveira MM, Silva-Filho MV, Cunha-Bastos VLF, Fernandes FC, Bastos JC (2007) Brain acetylcholinesterase as a marine pesticide biomarker using Brazilian fishes. Mar Environ Res 63:303-312

Oliveira JP, Santos RN, Pibernat CC, Boeira JM (2012) Genotoxicity and physical chemistry analysis of waters from Sinos River (RS) using Allium cepa and Eichhornia crassipes as bioindicators. Biochem Biotechnol Rep 1(1):15-22

Osório FHT, Silva LFO, Piancini LDS, Azevedo ACB, Liebel S, Yamamoto FY, Philippi VP, Oliveira MLS, Ortolani-Machado CF, Neto FF, Cestari MM, Assis HCS, Ribeiro CAO (2014) Water quality assessment of the Tubarão River through chemical analysis and biomarkers in the Neotropical fish Geophagus brasiliensis. Environ Sci Pollut Res Int 21(15):9145-9160

Parente TEM, De Oliveira ACAX, Silva IB, Araujo FG, Paumgarten FJR (2004) Induced alkoxyresorufin- $O$-dealkylases in tilapias (Oreochromis niloticus) from Gandu River, Rio de Janeiro, Brazil. Chemosphere 54:1613-1618

Parente TEM, De Oliveira ACAX, Paumgartten FJR (2008) Induced cytochrome P450 1A activity in cichlid fishes from Guandu River and Jacarepaguá Lake, Rio de Janeiro, Brazil. Environ Pollut 152:233-238

Payne JF, Mathieu A, Melvin W, Fancey LL (1996) Acetylcholinesterase, an old biomarker with a new future? Field trials in association with two urban rivers and a paper mill in Newfoundland. Mar Poll Bull 32:225-231

Pereira CDS, Abessa DMS, Bainy ACD, Zaroni LP, Gasparro MR, Bícego MC, Taniguchi S, Furley TH, Sousa ECPM (2007) Integrated assessment of multilevel biomarker responses and chemical analysis in mussels from São Sebastião, São Paulo, Brazil. Environ Toxicol Chem 26(3):462-469

Pereira CDS, Martin-Díaz ML, Zanette J, Cesar A, Choueri RB, Abessa DMS, Catharino MGM, Vasconcellos MBA, Bainy ACD, Sousa ECPM, Valls TAD (2011) Integrated biomarker responses as environmental status descriptors of a coastal zone (São Paulo, Brazil). Ecotoxicol Environ Safe 74:1257-1264

Pereira CDS, Abessa DMS, Choueri RB, Almagro-Pastor V, Cesar A, Maranho LA, Martin-Diaz LM, Torres RJ, Gusso-Choueri PK, Almeida JE (2014) Ecological relevance of sentinel's biomarker responses: a multi-level approach. Mar Environ Res 96:118-126

Pesce SF, Cazenave J, Monferrán MV, Frede S, Wunderlin DA (2008) Integrated survey on toxic effects of lindane on neotropical fish: Corydoras paleatus and Jenynsia multidentata. Environ Pollut 156:775-783

Prá D, Lau AH, Knakievicz T, Carneiro FR, Erdtmann B (2005) Environmental genotoxicity assessment of an urban stream using freshwater planarians. Mutat Res 585:79-85 
Prado LRGB, Felix C, Abessa DMS, Buruaem LM, Abujamara LD, Kirschbaum AA, Turatti GCR, Ranzani-Paiva MJT, Correia AT, Seriani R (2015) Hematological parameters and nuclear abnormalities in peripheral erythrocytes of Achirus lineatus (Pleuronectiformes: Achiridae). Comp Clin Pathol 24:169-175

Procópio MS, Ribeiro HJ, Pereira LA, Oliveira Lopes GA, Castro AC, Rizzo E, Sato Y, Russo RC, Corrêa JD (2014) Sexresponse differences of immunological and histopathological biomarkers in gill of Prochilodus argenteus from a polluted river in southeast Brazil. Fish Shellfish Immunol 39(1):108-117

Ranzani-Paiva MJT, Silva-Souza AT (2004) Co-infestation of gills by different parasite groups in the mullet, Mugil platanus Günther, 1880 (Osteichthyes, Mugilidae): effects on relative condition factor. Braz J Biol 64:677-682

Rechenmacher C, Siebel AM, Goldoni A, Klauck CR, Sartori T, Rodrigues MT, Gehlen G, Ardenghi P, Silva LB (2010) A multibiomarker approach in rats to assess the impact of pollution on Sinos River, southern Brazil. Braz J Biol 70(4):1223-1230

Ribeiro CAO, Katsumiti A, França P, Maschio J, Zandoná E, Cestari MM, Vicari T, Roche H, Assis HCS, Neto FF (2013) Biomarkers responses in fish (Atherinella brasiliensis) of Paranaguá Bay, Southern Brazil, for assessment of pollutant effects. Braz J Oceanogr 61(1):1-11

Richetti SK, Rosemberg DB, Ventura-Lima J, Monserrat JM, Bogo MR, Bonan CD (2011) Acetylcholinesterase activity and antioxidant capacity of zebrafish brain is altered by heavy metal exposure. Neurotoxicology 32:116-122

Rocha RM, Coelho RP, Montes CS, Santos SSD, Ferreira MAP (2010) Avaliação histopatológica de Brachyplatystoma rousseauxii (Castelnau, 1855) da Baía do Guajará, Belém, Pará. Ci Anim Bras 11(1):101-109

Rogero SO, Lugão AB, Ikeda TI, Cruz AS (2003) Teste in vitro de citotoxicidade: estudo comparativo entre duas metodologias. Mater Res 6:317-320

Rola RC, Monteiro MC, Reis SRS, Sandrini JZ (2012) Molecular and biochemical biomarkers responses in the mussel Mytilus edulis collected from Southern Brazil coast. Mar Pollut Bull 64:766-771

Ruas CBG, Carvalho CS, Araújo HSS, Espíndola ELG, Fernandes MN (2008) Oxidative stress biomarkers of exposure in the blood of cichlid species from a metal-contaminated river. Ecotoxicol Environ Safe 71:86-93

Sáenz LA, Seibert EL, Zanette J, Fiedler HD, Curtius AJ, Ferreira JF, Almeida EA, Marques MRF, Bainy ACD (2010) Biochemical biomarkers and metals in Perna perna mussels from mariculture zones of Santa Catarina, Brazil. Ecotoxicol Environ Safe 73:796-804

Santos PE, Kummrow F, Albergaria-Barbosa ACR, Bícego MC, Umbuzeiro GA (2010) Mutagenicity of blue rayon extracts of fish bile as a biomarker in a field study. Environ Mol Mutagen 51:173-179

Scalon MCS, Rechenmacher C, Siebel AM, Kayser ML, Rodrigues MT, Maluf SW, Rodrigues MAS, Silva LB (2010) Evaluation of Sinos River water genotoxicity using the comet assay in fish. Braz J Biol 70(4):1217-1222

Schulz UH, Martins-Junior H (2001) Astyanax fasciatus as bioindicator of water pollution of Rio dos Sinos, RS, Brazil. Braz J Biol 61(4):615-622

Seriani R, Moreira LB, Abessa DMS, Abujamara LD, Carvalho NSB, Maranho LA, Kirschbaum AA, Ranzani-Paiva MJT (2010) Hematological analysis of Micropogonias furnieri, Desmarest, 1823, Scianidae, from two estuaries of Baixada Santista, São Paulo, Brazil. Braz J Oceanogr 58:87-92

Seriani R, Abessa DMS, Kirschbaum AA, Pereira MJT, Ranzani-Paiva MJT, Assunção A, Silveira FL, Romano P, Mucci JLN (2012) Water toxicity and cyto-genotoxicity biomarkers in the fish Oreochromis niloticus (Cichlidae). J Braz Soc Ecotoxicol $7(2): 67-72$

Seriani R, Abessa DMS, Pereira CDS, Kirschbaum AA, Assunção A, Ranzani-Paiva MJT (2013) Influence of seasonality and pollution on the hematological parameters of the estuarine fish Centropomus parallelus. Braz J Oceanogr 61(2):105-111

Seriani R, Abessa DMS, Moreira LB, Cabrera JPG, Sanches JQ, Silva CLS, Amorim FA, Rivero DHRF, Silva FL, Fitorra LS, Carvalho-Oliveira R, Macchione M, Ranzani-Paiva MJT (2015) In vitro mucus transportability, cytogenotoxicity, and hematological changes as non-destructive physiological biomarkers in fish chronically exposed to metals. Ecotoxicol Environ Safe 112:162-168

Silva AG, Martinez CBR (2007) Morphological changes in the kidney of a fish living in an urban stream. Environ Toxicol Pharmacol 23:185-192

Silva DAM, Buzitis J, Krahn MM, Bícego MC, Pires-Vanin AMS (2006) Metabolites in bile of fish from São Sebastião Channel, São Paulo, Brazil as biomarkers of exposure to petrogenic polycyclic aromatic compounds. Mar Pollut Bull 52:175-183

Sousa DBP, Almeida ZS, Carvalho-Neta RNF (2013) Biomarcadores histológicos em duas espécies de bagres estuarinos da Costa Maranhense, Brasil. Arq Bras Med Vet Zootec 65(2):369-376

Souza TS, Fontanetti CS (2006) Micronucleus test and observation of nuclear alterations in erythrocytes of Nile tilapia exposed to waters affected by refinery effluent. Mutat Res 605:87-93

Souza DSM, Ramos APD, Nunes FF, Moresco V, Taniguchi S, Leal DAG, Sasaki ST, Bícego MC, Montone RC, Durigan M, Teixeira AL, Politto MR, Delfino N, Franco RMB, Melo CMR, Bainy ACD, Barardi CRM (2012) Evaluation of tropical water sources and mollusks in southern Brazil using microbiological, biochemical, and chemical parameters. Ecotoxicol Environ Safe 76:153-161

Souza IC, Duarte ID, Pimentel NQ, Rocha LD, Morozesk M, Bonomo MM, Azevedo VC, Pereira CDS, Monferrán MV, Milanez CRD, Matsumoto ST, Wunderlin DA, Fernandes MN (2013) Matching metal pollution with bioavailability, bioaccumulation and biomarkers response in fish (Centropomus parallelus) resident in neotropical estuaries. Environ Pollut 180:136-144

Souza-Bastos LR, Freire CA (2011) Osmoregulation of the resident estuarine fish Atherinella brasiliensis was still affected by an oil spill (Vicuña tanker, Paranaguá Bay, Brazil), 7 months after the accident. Sci Total Environ 409:1229-1234

Sureda A, Box A, Tejada S, Blanco A, Caixach J, Deudero S (2011) Biochemical responses of Mytilus galloprovincialis as biomarkers of acute environmental pollution caused by the Don Pedro oil spill (Eivissa Island, Spain). Aquat Toxicol 101:540-549 
Tice RR, Agurell E, Anderson D, Burlinson B, Hartmann A, Kobayashi H, Miyamae Y, Rojas E, Ryu JC, Sasaki YF (2000) Single cell gel/comet assay: guidelines for in vitro and in vivo genetic toxicology testing. Environ Mol Mutagen 35(3):206-221

Torres MA, Testa CP, Gáspari C, Masutti MB, Panitz CMN, Curi-Pedrosa R, Almeida EA, Mascio P, Filho DW (2002) Oxidative stress in the mussel Mytella guyanensis from polluted mangroves on Santa Catarina Island, Brazil. Mar Pollut Bull 44(9):923-932

Tortelli V, Colares EP, Robaldo RB, Nery LEM, Pinho GLL, Bianchini A, Monserrat JM (2006) Importance of cholinesterase kinetic parameters in environmental monitoring using estuarine fish. Chemosphere 65:560-566

Toste R, Fernandez MA, Pessoa IA, Parahyb MA, Dore MP (2011) Organotin pollution at Arraial do Cabo, Rio de Janeiro State, Brazil: increasing levels after the TBT ban. Braz J Oceanogr 59(1):111-117

Trapp J, Armengaud J, Salvador A, Chaumot A, Geffard O (2014) Next-generation proteomics: toward customized biomarkers for environmental biomonitoring. Environ Sci Technol 48:13560-13572

Udroiu I (2006) The micronucleus test in piscine erythrocytes. Aquat Toxicol 79(2):201-204

Valbonesi P, Sartor G, Fabbri E (2003) Characterization of cholinesterase activity in three bivalves inhabiting the North Adriatic sea and their possible use as sentinel organisms for biosurveillance programmes. Sci Total Environ 312(1-3):79-88

Van der Oost R, Beyer J, Vermeulen NPE (2003) Fish bioaccumulation and biomarkers in environmental risk assessment: a review. Environ Toxicol Pharmacol 13:149-157

Venancio LP, Silva MI, Silva TL, Moschetta VA, Campos-Zuccari DA, Almeida EA, Bonini-Domingos CR (2013) Pollutioninduced metabolic responses in hypoxia-tolerant freshwater turtles. Ecotoxicol Environ Safe 97:1-9

Ventura EC, Gaelzer LR, Zanette J, Marques MRF, Bainy ACD (2002) Biochemical indicators of contaminant exposure in spotted pigfish (Orthopristis ruber) caught at three bays of Rio de Janeiro coast. Mar Environ Res 54:775-779

Viarengo A, Canesi L, Pertica M, Poli G, Moore MN, Orunesu M (1990) Heavy metal effects on lipid peroxidation in the tissues of Mytilus galloprovincialis lam. Comp Biochem Physiol Part C Toxicol Pharmacol 97(1):37-42

Viarengo A, Lowe D, Bolognesi C, Fabbri E, Koehler A (2007) The use of biomarkers in biomonitoring: a 2-tier approach assessing the level of pollutant induced stress syndrome in sentinel organisms. Comp Biochem Physiol C Toxicol Pharmacol 146:281-300

Vieira CED, Almeida MS, Galindo BA, Pereira L, Martinez CBR (2014) Integrated biomarker response index using a neotropical fish to assess the water quality in agricultural areas. Neotrop Ichthyol 12(1):153-164

Villela IV, Oliveira IM, Silva J, Henriques JAP (2006) DNA damage and repair in haemolymph cells of golden mussel (Limnoperna fortunei) exposed to environmental contaminants. Mutat Res 605:78-86

Villela IV, Oliveira IM, Silveira JC, Dias JF, Henriques JAP, Silva J (2007) Assessment of environmental stress by the micronucleus and comet assays on Limnoperna fortunei exposed to Guaíba hydrographic region samples (Brazil) under laboratory conditions. Mutat Res 628:76-86

Ward D, Simpson S, Jolley D (2013) Slow avoidance response to contaminated sediments elicits sublethal toxicity to benthic invertebrates. Environ Sci Technol 47:5947-5953

WHO International Programme on Chemical Safety (IPCS) (1993) Biomarkers and risk assessment: concepts and principles. Environmental Health Criteria 155. World Health Organization, Geneva

Zanette J, Monserrat JM, Bianchini A (2006) Biochemical biomarkers in gills of mangrove oyster Crassostrea rhizophorae from three Brazilian estuaries. Comp Biochem Physiol C Toxicol Pharmacol 143(2):187-195

Zanette J, Nunes FF, Medeiros ID, Siebert MN, Mattos JJ, Lüchmann KH, Melo CMR, Bainy ACD (2008) Comparison of the antioxidant defense system in Crassostrea rhizophorae and Crassostrea gigas exposed to domestic sewage discharges. Mar Environ Res 66:196-198

Zanette J, Monserrat JM, Bianchini A (2015) Biochemical biomarkers in barnacles Balanus improvisus: pollution and seasonal effects. Mar Environ Res 103:74-79

Zapata LM, Bock BC, Orozco LY, Palacio JA (2016) Application of the micronucleus test and comet assay in Trachemys callirostris erythrocytes as a model for in situ genotoxic monitoring. Ecotoxicol Environ Safe 127:108-116

Zegura B, Heath E, Cernosa A, Filipic M (2009) Combination of in vitro bioassays for the determination of cytotoxic and genotoxic potential of wastewater, surface water and drinking water samples. Chemosphere 75:1453-1460

Zinkl JG, Lockhart WL, Kenny SA, Ward FJ (1991) The effects of cholinesterase inhibiting insecticides on fish. Cholinesteraseinhibiting insecticides chemicals in agriculture, vol 2. Elsevier, Amsterdam, pp 109-125 